\title{
IMPLEMENTASI KURIKULUM BERBASIS PESANTREN DI MI NURUL ULUM KRETEK BANTUL
}

\author{
Siti Sholehah, Sukati \\ Pendidikan Guru Madrasah Ibtidaiyah Universitas Alma Ata \\ sukati79@almaata.ac.id
}

\begin{abstract}
Abstrak
Penelitian ini berawal dari ketertarikan peneliti terhadap MI Nurul Ulum Kretek Bantul sebagai salah satu madrasah yang menerapkan kurikulum menurut sistem pendidikan nasional yang di integrasikan dengan kurikulum berbasis pesantren. Penelitian ini bertujuan untuk mengetahui bagaimana perencanaan, implementasi, pemantauan, dan evaluasi kurikulum di MI Nurul Ulum. Jenis penelitian ini adalah penelitian kualitatif. Subyek dari penelitian ini adalah kepala sekolah dan guru. Teknik analisis data dilakukan dengan analisis deskriptif. Teknik dan instrumen pengumpulan data adalah teknik observasi, wawancara dan dokumentasi. Pada teknik uji keabsahan data peneliti menggunakan teknik triangulasi. Hasil penelitian menunjukkan bahwa: manajemen kurikulum berbasis pesantren di MI Nurul Ulum Kretek Bantul adalah sebagai berikut: 1. Perencanaan manajemen kurikulum berbasis pesantren sudah berjalan sesuai yang telah direncanakan seperti persiapan mengajar dan program sekolah lainnya, perencanan dilakukan pada tahun ajaran baru yang melibatkan kepala sekolah, guru, ketua yayasan dan benerapa komite. 2. Pelaksanaan manajemen kurikulum di MI Nurul Ulum di bedakan menjadi dua tingkatan yaitu tingkat sekolah yang berada dibawah pimpinan kepala sekolah dan kurikulum tingkat kelas yang berada di bawah pimpinan guru. 3. Pengawasan manajemen kurikulum dilaksanakan pada saat berlangsungnya kegiatan pelaksanaan kurikulum dengan menggunakan metode observasi kelas dan musyawarah. 4. Evaluasi manajemen kurikulum dilaksanakan tidak hanya sekali dalam setahun akan tetapi setiap ada kendala sehingga kendala yang ada tidak menumpuk.
\end{abstract}

Kata kunci: Manajemen, kurikulum berbasis pesantren.

\begin{abstract}
This reseach is started by researcher interest to MI Nurul Ulum Kretek Bantul as one of madrasah which apply curriculum based on national education system which integrated pesantren basedcurriculum. This reseach aims to know about planning, implementing, monitoring, and evaluating those curriculums in MI Nurul Ulum. The type of this research is qualitative research. Subject of this research is the headmaster and some teachers. The technique of data analysis is using descriptiveanalysis. Techniques and instrument of data collection is using observation, interview and documentation technique. To test the data validity, the researcher use triangulation technique. The finding of this research show that managements of pesantren based-curriculum in MI Nurul Ulum Kretek Bantul are as presented: 1. The planning of management pesantren based-curriculum already well running such as teaching preparation and other school programs, the preparation is carried out in early year school involving the headmaster and teacher, the foundation's president, and commitees. 2. The implementation of curriculum management in MI Nurul Ulum is divided into 2 levels of studies : in school level is under headmaster leadership and class level is under teacher leadership. 3. The monitoring of curriculum management is conducted during the implementation of curriculum activities using observation and deliberation in class. 4. Evalution of curriculum
\end{abstract}


management is conducted not only once in a year, but also every time when the obstacles occured, so the existing constraints do not accumulate.

Keywords : Management, Pesantren-based curriculum

\section{A. PENDAHULUAN}

Pendidikan adalah usaha sadar dan terencana untuk mewujudkan suasana belajar dan proses pembelajaran agar peserta didik secara aktif mengembangkan potensi dirinya untuk memiliki kekuatan spiritual keagamaan, pengendalian diri, kepribadian, kecerdasan, akhlak mulia, serta keterampilan, yang diperlukan dirinya, masyarakat, bangsa, dan Negara. ${ }^{1}$ Pendidikan merupakan sarana terpenting dalam usaha pembangunan sumber daya manusia dan penanaman nilai-nilai kemanusiaan yang mengarah pada tatanan kehidupan masyarakat yang beradab dan berperadaban. Nilainilai kemanusiaan itu menjadikan sebuah konsep kehidupan yang lebih sempurna sesuai ajaran Islam. ${ }^{2}$

Pendidikan adalah merupakan suatu masalah yang sangat penting dalam kehidupan manusia. Maju tidaknya suatu bangsa sangat tergantung pada pendidikan bangsa tersebut. Artinya jika pendidikan suatu bangsa dapat menghasilkan manusia berkualitas lahir batin. Otomatis bangsa tersebut akan maju, damai dan tentram. Sebaliknya jika pendidikan suatu bangsa mengalami stagnasi maka bangsa itu akan terbelakang di segala bidang. ${ }^{3}$

Fenomena pendidikan yang menampilkan wajah keberagaman utamanya Islam, kini mulai marak berkembang dan popular di tengah-tengah kehidupan bermasyarakat. Fenomena pendidikan itu mewujud dalam bentuk penggabungan antara pendidikan formal serta informal yang terbalut dalam satu bingkai lembaga atau satuan pendidikan. Pendidikan mengintegrasikan (Integrated Education) antara pendidikan umum dan pendidikan agama. Bentuk pendidikan terintegrasi itu bisa dilihat dari pendidikan pesantren atau yang populer disebut Boarding School. Pendidikan yang populer secara umum di Indonesia. Model yang menggabungkan antara pendidikan umum dan agama, namun pada sisi luar, orang menganggap nuansa agama sangat kental.

\footnotetext{
${ }^{1}$ Ara Hidayat dan Imam Machali, Pengelolaan Pendidikan, Yogyakarta : Kaukaba, 2012, hlm. 29

${ }^{2}$ Wan Mohd Nor Wan Daud, Filsafat dan Praktik Pendidikan Islam Syed M. Naquid Al-Attas, Bandung: Mizan, 2003, hlml. 23

${ }^{3}$ Hairiyah, Konsep Manajemen Mutu Terpadu Dalam Pendidikan, Jurnal Ilmu Pendidikan, Vol.VI, No. 1 juni 2015, hlm. 111
} 
Pesantren merupakan lembaga pendidikan Islam yang dibentuk oleh masyarakat guna memenuhi kebutuhan pendidikan anggotanya, pesantren akan terus eksis jika mampu memenuhi kebutuhan masyarakatnya. Sebaliknya masyarakat akan menarik kepercayaan pendidikan anggotanya jika saja pesantren tidak mampu memenuhi kebutuhan yang diharapkan masyarakatnya. Pendidikan pesantren menurut Mastuhu seperti yang dikutip dalam Damopili bertujuan untuk menciptakan dan mengembangkan kepribadian muslim, yaitu kepribadian yang beriman dan bertakwa kepada tuhan, berakhlak mulia, bermanfaat bagi masyarakat. ${ }^{4}$

Pentingnya pendidikan seperti yang dijelaskan dalam QS: At-Taubah ayat 122 yang artinya tidak sepatutnya bagi mukminin itu pergi semuanya (ke medan perang). Mengapa tidak pergi dari tiap-tiap golongan diantara mereka beberapa orang untuk memperdalam pengetahuan mereka tentang agama dan untuk memberi peringatan kepada kaumnya apabila mereka telah kembali kepadanya, supaya mereka itu dapat menjaga dirinya, hal tersebut tercantum dalam Al-Quran surat At- Taubah ayat:122. Kandungan ayat tersebut menjelaskan bahwa tidak semua mukmin dituntut untuk berangkat berperang tetapi juga dituntut untuk mendalami agama, yang tujuan utamanya adalah ingin membimbing kaumnya, mengajari mereka tentang akibat kebodohan dan tidak mengamalkan apa yang mereka ketahui. Ayat tersebut merupakan isyarat wajibnya pendalaman agama dan bersedia mengajarkannya di tempat-tempat pemukiman serta memahamkan orang-orang lain kepada agama.

Pesantren dengan segala keunikan yang dimilikinya masih diharapkan menjadi penopang berkembangnya sistem pendidikan di Indonesia. Keaslian dan kekhasan pesantren di samping sebagai khasanah tradisi budaya bangsa juga merupakan kekuatan penyangga pilar pendidikan untuk memunculkan pemimpin bangsa yang bermoral. Oleh sebab itu, arus globalisasi mengandaikan tuntutan profesionalisme dalam mengembangkan sumber daya manusia yang bermutu. Realitas inilah yang menuntut adanya manajemen pengelolaan lembaga pendidikan sesuai tuntutan zaman. ${ }^{5}$

Salah satu aspek yang berpengaruh terhadap keberhasilan pendidikan nasional adalah aspek kurikulum. Kurikulum merupakan salah satu komponen yang memiliki

\footnotetext{
${ }^{4}$ Mastuhu dalam Maljono Damopoli, Pesantren Modern IMMIM Pencetak Muslim Modern (Jakarta: Rajawali Pers, 2011) hlm. 82.

5 Ainurrafiq Dawam dan Ahmad Ta'arifin, Manajemen Madrasah Berbasis Pesantren, Listafariska Putra: 2005, hlm. 18
} 
peran strategis dalam sistem pendidikan. Kurikulum merupakan suatu sistem program pembelajaran yang dimaksudkan untuk mencapai tujuan intitusional pada lembaga pendidikan, sehingga kurikulum memegang peranan penting dalam mewujudkan sekolah yang bermutu dan berkualitas. ${ }^{6}$ Manajemen kurikulum khususnya merupakan substansi manajemen yang utama di sekolah. Prinsip dasar manajemen kurikulum ini adalah berusaha agar proses pembelajaran dapat berjalan dengan baik. $^{7}$

Kurikulum berbasis pesantren berarti memasukan kurikulum pesantren ke dalam kurikulum madrasah. Perbedaan yang tampak antara madrasah pada umumnya dengan madrasah dengan kurikulum berbasis pesantren adalah jika pada kurikulum PAI di madrasah pada umumnya hanya meliputi mata pelajaran Qur'an Hadis, Fiqih, Aqidah Akhlak, dan Sejarah Kebudayaan Islam, maka di madrasah yang menerapkan kurikulum berbasis pesantren memiliki cakupan pelajaran yang lebih luas karena ditambah pelajaran dari pesantren.

Madrasah Ibtidaiyah Nurul Ulum ini memiliki tujuan untuk mengintegrasikan program Pondok Pesantren ke dalam kurikulum sekolah yaitu kurikulum yang sesuai dengan sistem pendidikan nasional yang diintegrasikan dan dikembangkan dengan kurikulum program pondok pesantren Nurul Ulum. Kurikulum yang diterapkan di MI Nurul Ulum adalah kurikulum 2013 untuk kelas 1,2,4 dan 5 sedangkan untuk kelas 3 menggunakan kurikulum KTSP.

Berdasarkan kenyataan tersebut, peneliti tertarik untuk untuk mengetahui manajemen kurikulum di MI Nurul Ulum Kretek Bantul. Alasan peneliti memilih MI Nurul ulum karena Kurikulum yang digunakan di MI Nurul Ulum adalah kurikulum menurut sistem pendidikan nasional yang diintegrasikan dan dikembangkan dengan kurikulum sesuai dengan program pondok pesantren Nurul Ulum.

\section{B. METODE PENELITIAN}

Penelitian ini menggunakan pendekatan kualitatif deskriptif. Metode penelitian kualitatif merupakan metode penelitian yang penelitiannya dilakukan secara alamiah. Alamiah adalah data yang diperoleh apa adanya, tidak dimanipulasi oleh peneliti dan peneliti tidak mempengaruhi perubahan objek penelitian. Metode kualitatif ini digunakan

\footnotetext{
${ }^{6}$ Muhammad Kristiawan. Dkk, Manajemen Pendidikan, Yogyakarta : Deepublish : 2017, hlm. 76.

${ }^{7}$ Dinn Wahyudin, Manajemen Kurikulum, Bandung : PT Remaja Rosdakarya, 2014, hlm. 18.
} 
untuk mendapatkan data yang mendalam. Oleh karena itu metode kualitatif tidak menekankan pada generalisasi, tetapi lebih menekankan pada makna. ${ }^{8}$

Dalam penelitian ini peneliti menggunakan metode penelitian kualitatif deskriptif dengan jenis studi kasus, data yang diperoleh berbentuk kata-kata atau deskripsi manajemen pendidikan berbasis pesantren di MI Nurul Ulum. Subyek penelitian adalah orang yang menjadi sumber informasi yang dapat memberikan data yang sesuai dengan masalah yang diteliti. Pada penelitian ini subyek penelitian terdiri dari kepala sekolah, guru, dan perwakilan siswa. Teknik pengumpulan data menggunakan observasi, wawancara dan dokumentasi.

Teknik keabsahan yang dilakukan dengan metode triangulasi teknik yakni untuk menguji kradibilitas data. Pengujian dilakukan dengan cara mengecek data dari sumber yang sama dengan teknik pengumpulan data yang berbeda. ${ }^{9}$ Sebagaimana gambar di bawah ini:

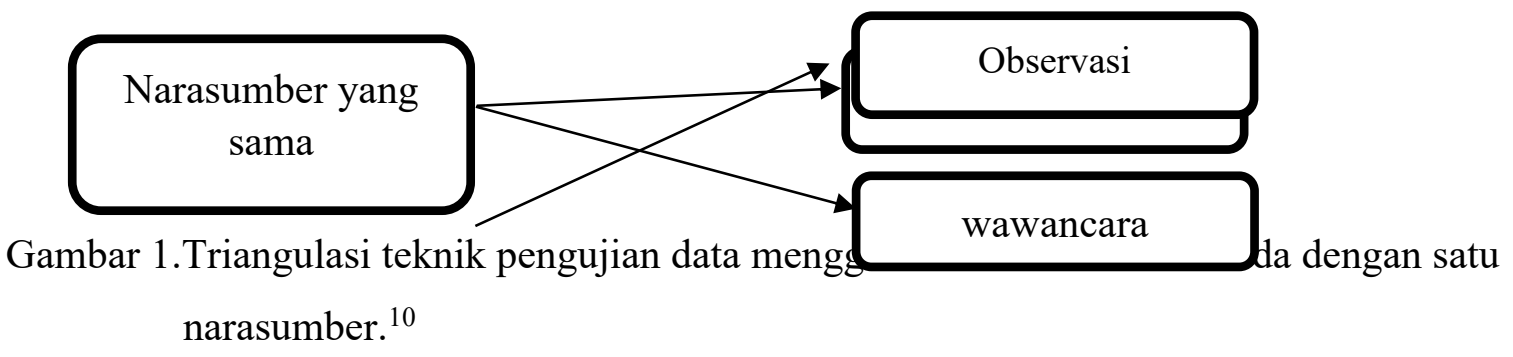

Analisis data dengan cara mengorganisasikan data, menjabarkannya dengan unitunit, melakukan sintesa, menyusun ke dalam pola, memilih mana yang penting dan yang akan dipelajari, dan membuat simpulan yang dapat diceritakan kepada orang lain. Langkah-langkah analisis ditunjukkan pada gambar berikut:

\footnotetext{
${ }^{8}$ Sugiyono, Metode Penelitian Pendidikan Pendekatan Kuantitatif, Kualitatif, dan R\&D, Bandung : ALFABETA, 2012, hlm.14.

${ }^{9}$ Sugiyono, Metode Penelitian Pendidikan Pendekatan Kuantitatif, Kualitatif, dan R\&D, Bandung: ALFABETA, 2012, hlm.374

${ }^{10}$ Ibid., hlm.372
} 




Gambar 2 Teknik analisis data dengan model Miles dan Huberman ${ }^{11}$

\section{HASIL DAN PEMBAHASAN}

Manajemen (pengelolaan) kurikulum berbasis pesantren di MI Nurul Ulum, antara lain sebagai berikut:

\section{Perencanaan Kurikulum Berbasis Pesantren di MI Nurul Ulum Kretek Bantul}

Kurikulum yang diterapkan di MI Nurul Ulum adalah kurikulum 2013 untuk kelas 1,2,4 dan 5 sedangkan untuk kelas 3 menggunakan kurikulum KTSP, kurikulum yang diterapkan mengikuti aturan dari pemerintah.

Perencanaan kurikulum berbasis pesantren di MI Nurul Ulum dilaksanakan setiap awal tahun ajaran baru. Perencanaan kurikulum ini sebagai wujud tindak lanjut dari hasil evaluasi yang diadakan setiap akhir tahun ajaran.

Berdasarkan keterangan kepala sekolah dapat diketahui bahwa sekolah melakukan perencanaan kurikulum dengan mengadakan rapat perencanaan kurikulum yang dilaksanakan sebelum tahun ajaran baru dan menggunakan hasil rapat evaluasi kurikulum sebagai pertimbangan untuk penyusunan kurikulum yang akan digunakan satu tahun ke depan.

Adapun yang terlibat dalam perencanaan kurikulum berbasis pesantren adalah seluruh elemen mulai dari kepala sekolah, guru, ketua yayasan, dan perwakilan komite wali santri. Berdasarkan hasil penelitian dapat diketahui bahwa tidak hanya

\footnotetext{
${ }^{11}$ Ibid., hlm 337
} 
dari pihak sekolah yang merencanakan kurikulum akan tetapi juga ada dari pihak yayasan yang selalu terlibat dalam perencanaan kurikulum.

Secara spesifik tujuan diterapkanya kurikulum berbasis pesantren di MI Nurul Ulum adalah supaya bisa integratif dengan kegiatan yang ada di pondok pesantren, lebih lanjut salah satu pendidik di MI Nurul Ulum menyatakan bahwa pendidikan berbasis pesantren berbeda dengan pendidikan yang di luar pesantren, jika di luar anak-anak pasti dengan orang tuanya berbeda dengan di pesantren anak-anak melakukan apa-apa sendiri. Kepala sekolah MI Nurul Ulum juga menyatakan mengatakan bahwa materi yang diajarkan di MI Nurul Ulum secara umum sama dengan mata pelajaran yang ada di kurikulum 2013, yang membedakan dari pesantren yang memiliki ciri khas tahfidz dan fokus pada hafalan Al-Qur'an anak.

Selain itu berdasarkan hasil penelitian dapat diketahui bahwa usaha MI Nurul Ulum dalam mengintegrasikan antara pesantren dengan sekolah adalah membantu dalam hal akhlak, karena ketika di pesantren setiap sepuluh anak diampu oleh satu ustad/ustadzah dan itu tidak bisa intensif jika untuk mempelajari semuanya. Tujuanya adalah supaya anak bisa menghafal Al-qur'an dan mempunyai akhlak yang baik juga. Selain pada akhlak kurikulum pesantren MI Nurul Ulum juga menambahkan beberapa pelajaran khusus seperti yang ada pada kurikulum muatan lokal.

Evaluasi pembelajaran yang dilaksanakan di MI Nurul Ulum ada dua bentuk yaitu tes tertulis dan tidak tertulis. Tes tertulis ini dilakasanakan untuk mengetahui sejauh mana peserta didik menguasai materi yang telah disampaikan oleh gurunya selama proses pembelajaran. Tes yang tidak tertulis berupa pengamatan terhadap sikap siswa setelah menerima pelajaran tersebut.

Kepala sekolah MI Nurul Ulum menambahkan bahwa selain dalam bentuk tertulis dan tidak tertulis, evaluasi pembelajaran di MI Nurul Ulum menggunakan sistem setoran hafalan. Adapun sasaranya adalah mengetahui kemampuan siswa dalam menghafal. Hal ini tentunya untuk mewujudkan target yang ditentukan oleh pesantren ketika siswa lulus MI hafal 30 juz Al-Qur'an.

\section{Pelaksanaan Kurikulum Berbasis Pesantren di MI Nurul Ulum Kretek Bantul}

Pelaksanaan kurikulum berbasis pesantren di MI Nurul Ulum berjalan di bawah pengawasan kepala sekolah. Kepala sekolah menjalankan tugas pelaksanaan kurikulum di tingkat sekolah seperti melakukan koordinasi kegiatan guru-guru, serta 
melaksanakan segala kegiatan yang telah direncanakan sebagai usaha mencapai tujuan kurikulum. Pelaksanaan kurikulum di masing-masing kelas menjadi tanggung jawab dari masing-masing guru.

Berdasarkan hasil penelitian dapat diketahui bahwa pelaksanaan kurikulum di MI Nurul Ulum Kretek Bantul dibedakan menjadi dua tingkatan, yaitu pelaksanaan tingkat sekolah dan pelaksanaan tingkat kelas. Kepala sekolah menjalankan kurikulum di tingkat sekolah dan guru yang menjalankan kurikulum di tingkat kelas, namun tetap ada arahan dari kepala sekolah.

Guru memiliki peran penting dalam pelaksanaan kurikulum tingkat kelas. Peran guru sebagai pengendali proses belajar mengajar di dalam kelas secara otomatis memberikan tanggung jawab guru dalam manajemen pelaksanaan kurikulum di tingkat kelas. Pada tahap ini, guru memiliki beberapa tugas seperti membuat rencana program untuk satu tahun (prota), program satu semester (promes), silabus, dan membuat rencana pembelajaran (RPP).

Berdasarkan hasil penelitian juga dapat diketahui bahwa guru membuat perangkat pembelajaran pada awal tahun pembelajaran. Tepatnya sebelum tahun ajaran baru dimulai. Setiap guru diwajibkan mengumpulkan perangkat pembelajaran tersebut kepada kepala sekolah, perangkat pembelajaran tersebut kemudian akan dikoreksi apakah RPP, prota, promes sudah sesuai dengan aturan yang ditetapkan.

Berdasarkan hasil penelitian dapat disimpulkan bahwa guru mengerjakan tugas administrasi guru pada awal tahun ajaran atau sebelum tahun ajaran baru dimulai. Dokumen administrasi guru diserahkan kepada kepala sekolah untuk dikaji dan dijadikan sebagai upaya mendampingi dan mengawasi jalannya pelaksanaan kurikulum di sekolah.

Secara umum mata pelajaran yang diterapkan di MI Nurul Ulum sama dengan sekolah lain baik mata pelajaran umum juga pelajaran PAI. Untuk mata pelajaran PAI tidak ada tambahan, akan tetapi ada waktu tersendiri untuk mengimplementasikan pendidikan pesantrennya.

Bentuk implementasi pendidikan berbasis pesantren adalah adanya jadwal tersendiri yang mempelajari tentang tajwid, fasholatan, dan imla' pada jam tertentu, di MI Nurul Ulum pelajaran tersebut diajarkan pada waktu pagi setelah sholat dhuha dan siang setelah sholat dzuhur, ada guru khusus untuk mempelajari materi tersebut. 
Secara garis besar implementasi kurikulum di MI Nurul Ulum sudah berjalan walaupun ada beberapa kendala tapi secara keseluruhan sudah sesuai dengan apa yang sudah direncanakan.

Hambatan dalam implementasinya dapat dilihat dari gedung yang belum memadai, tidak adanya sistem kontrak dari ustadz/ustadzah sehingga sering bergantiganti, dari faktor siswa sendiri berasal dari lingkungan dan keluarga yang berbedabeda.

\section{Pengawasan Kurikulum Berbasis Pesantren di MI Nurul Ulum Kretek Bantul}

Pengawasan kurikulum di MI Nurul Ulum dilaksanakan pada saat berlangsungnya kegiatan pelaksanaan kurikulum. Adapun yang terlibat dalam pengawasan kurikulum di MI Nurul Ulum adalah ketua yayasan, kepala sekolah, dan semua guru juga dilibatkan

Pengawasan Kurikulum di MI Nurul Ulum dilaksanakan oleh kepala madrasah setiap minggu, tujuannya bukan hanya mencari kesalahan guru tetapi juga untuk melakukan perbaikan. Dengan adanya kegiatan pengawasan ini, seorang guru mampu melaksanakan pembelajaran secara efektif dan bermakna.

Adapun Aspek-aspek yang diawasi dalam pengawasan kurikulum antara lain: perangkat pembelajaran, sarana prasarana pembelajaran, proses pembelajaran, SDM, dan evaluasi pembelajaran. Metode yang digunakan pada saat pengawasan kurikulum di MI Nurul Ulum secara umum meliputi kunjungan dan observasi kelas, pembicaraan individu dan musyawarah. Pada saat pengawasan kurikulum MI Nurul Ulum tidak menggunakan pedoman secara khusus atau tertulis. Bentuk tindak lanjut dari pengawasan kurikulum adalah evaluasi kurikum.

\section{Evaluasi Kurikulum Berbasis Pesantren di MI Nurul Ulum Kretek Bantul}

Evaluasi kurikulum merupakan salah satu kegiatan penting di sekolah yang harus dilaksanakan karena dengan evaluasi kurikulum dapat diketahui kekurangan dan kelemahannya. Kegiatan ini dilaksanakan setiap akhir tahun ajaran. Berdasarkan hasil wawancara, peneliti dapat menyimpulkan bahwa evaluasi mengenai kurikulum tidak hanya dilaksanakan setiap akhir saja, tetapi setiap bulan agar masalah yang ada bisa cepat diselesaikan sehingga tidak menumpuk ketika evaluasi diakhir tahun. Lebih 
lanjut ada beberapa metode yang digunakan pada saat evaluasi di MI Nurul Ulum yaitu rapat koordinasi dan pendekatan personal.

Pendekatan secara personal dilakukan Kepala Sekolah kepada guru, ustad/ustadzah juga kepada siswa jika ada kendala atau masalah sehingga semuanya dapat diselesaikan secara bersama. Di sisi lain objek pada saat evaluasi adalah SDM, siswa, sarana prasarana, materi ajar, dan metode pembelajaran.

Ada beberapa pihak yang terlibat dalam evaluasi kurikulum, diantaranya ketua yayasan, kepala madrasah, guru, ustadz/ustadzah, dan komite madrasah. Kepala madrasah berperan dalam pengendalian sistem evaluasi, agar evaluasi dapat dilaksanakan sesuai dengan yang sudah direncanakan. Kepala sekolah bekerjasama dengan guru untuk melakukan evaluasi dengan objektif agar hasil evaluasi sesuai yang diharapkan. Metode evaluasi kurikulum yang digunakan di MI Nurul Ulum yaitu menggunakan pendekatan secara personal atau individu dan musyawarah untuk memecahkan masalah yang ada.

Dengan diberlakukannya kurikulum berbasis pesantren dari pihak MI Nurul Ulum mengharapkan lulusan yang tidak hanya menguasai pengetahuan umum dan juga agama tapi juga bisa menghafal Al-Qur'an sesuai dengan ciri khas MI Nurul Ulum.

Dari hasil penelitian yang telah dilaksanakan, pembahasan dari hasil penelitian dapat dilihat sebagai berikut:

\section{Perencanaan Implementasi kurikulum pesantren di MI Nurul Ulum Kretek Bantul}

Perencanaan kurikulum merupakan tahap yang pertama dalam proses penyusunan kurikulum. Agar sebuah kurikulum memberikan hasil yang optimal, maka harus direncanakan mulai dari desain, implementasi, sampai kepada evaluasinya. $^{12}$

Perencanaan kurikulum berbasis pesantren di MI Nurul Ulum adalah sebagai berikut:

a. Kurikulum yang diterapkan di MI Nurul Ulum adalah kurikulum 2013 untuk kelas I,II,IV dan V sedangkan untuk kelas III menggunakan kurikulum KTSP, kurikulum yang diterapkan mengikuti aturan dari pemerintah

\footnotetext{
${ }^{12}$ Dinn Wahyudin, Manajemen Kurikulum, Bandung : PT Remaja Rosdakarya, 2014, hlm. 81.
} 
b. Perencanaan kurikulum berbasis pesantren di MI Nurul Ulum dilaksanakan setiap awal tahun ajaran baru. Perencanaan kurikulum ini sebagai wujud tindak lanjut dari hasil evaluasi yang diadakan setiap akhir tahun ajaran.

c. Sekolah melakukan perencanaan kurikulum dengan mengadakan rapat perencanaan kurikulum yang dilaksanakan sebelum tahun ajaran baru dan menggunakan hasil rapat evaluasi kurikulum sebagai pertimbangan untuk penyusunan kurikulum yang akan digunakan satu tahun ke depan.

d. Tujuan diterapkanya kurikulum berbasis pesantren di MI Nurul Ulum adalah supaya bisa integratif dengan kegiatan yang ada di pondok pesantren

e. Evaluasi pembelajaran yang dilaksanakan di MI Nurul Ulum ada dua bentuk yaitu tes tertulis dan tidak tertulis. Tes tertulis ini dilakasanakan untuk mengetahui sejauh mana peserta didik menguasai materi yang telah disampaikan oleh gurunya selama proses pembelajaran. Tes tidak tertulis berupa pengamatan terhadap sikap siswa setelah menerima pelajaran tersebut.

\section{Pelaksanaan Implementasi Kurikulum Pesantren di MI Nurul Ulum Kretek}

\section{Bantul}

Pelaksanaan kurikulum merupakan tahapan yang perlu dilakukan, karena yang menjadi ukuran kesuksesan sebuah implementasi kurikulum pada dasarnya dapat dilihat dari sejauh mana pengembang kurikulum memiliki kemampuan dan kemauan untuk mengakomodasi kemungkinan dilakukannya modifikasi dalam kurikulum yang dirancang. ${ }^{13}$

Pelaksanaan manajemen kurikulum berbasis pesantren di MI Nurul Ulum adalah sebagai berikut:

a. Pelaksanaan kurikulum berbasis pesantren di MI Nurul Ulum berjalan di bawah pengawasan kepala sekolah. Kepala sekolah menjalankan tugas pelaksanaan kurikulum ditingkat sekolah seperti melakukan koordinasi kegiatan guru-guru, serta melaksanakan segala kegiatan yang telah direncanakan sebagai usaha mencapai tujuan kurikulum.

b. Pelaksanaan kurikulum di MI Nurul Ulum Kretek Bantul dibedakan menjadi dua tingkatan, yaitu pelaksanaan tingkat sekolah dan pelaksanaan tingkat kelas. Kepala sekolah menjalankan kurikulum di tingkat sekolah dan guru yang

${ }^{13}$ Ibid., hlm. 94-95 
menjalankan kurikulum di tingkat kelas, namun tetap ada arahan dari kepala sekolah.

c. Guru memiliki peran penting dalam pelaksanaan kurikulum tingkat kelas. Peran guru sebagai pengendali proses belajar mengajar di dalam kelas secara otomatis memberikan tanggung jawab guru dalam manajemen pelaksanaan kurikulum di tingkat kelas. Setiap guru diwajibkan mengumpulkan perangkat pembelajaran kepada kepala sekolah, perangkat pembelajaran tersebut kemudian akan dikoreksi apakah RPP, prota, promes sudah sesuai dengan aturan yang ditetapkan.

d. Secara umum mata pelajaran yang diterapkan di MI Nurul Ulum sama dengan sekolah lain baik mata pelajaran umum juga pelajaran PAI.

e. Secara garis besar implementasi kurikulum di MI Nurul Ulum sudah berjalan walaupun ada beberapa kendala tapi secara keseluruhan sudah sesuai dengan apa yang sudah direncanakan.

\section{Pengawasan Implementasi Kurikulum Pesantren di MI Nurul Ulum Kretek}

\section{Bantul}

Menurut Dinn Wahyudin tujuan utama dari pemantauan kurikulum adalah untuk memperoleh informasi agar dilakukan perbaikan dan peningkatan kualitas pembelajaran sekaligus pembinaan dalam pelaksanaan pembelajaran sehingga terus dilakukan peningkatan mutu pembelajaran dan profesionalisme guru. ${ }^{14}$ Pemantauan kurikulum merupakan kegiatan untuk mengamati secara langsung implementasi kurikulum secara mantap, teratur dan terus menerus dengan cara mendengar, melihat dan menelusuri, serta mencatan keadaan dan perkembangannya. $^{15}$

Pengawasan kurikulum berbasis pesantren di MI Nurul Ulum adalah sebagai berikut:

a. Pengawasan kurikulum di MI Nurul Ulum dilaksanakan pada saat berlangsungnya kegiatan pelaksanaan kurikulum. Yang terlibat dalam pengawasan kurikulum di MI Nurul Ulum adalah ketua yayasan, kepala sekolah, dan semua guru. 
b. Adapun Aspek-aspek yang diawasi dalam pengawasan kurikulum antara lain: perangkat pembelajaran, sarana prasarana pembelajaran, proses pembelajaran, SDM, dan evaluasi pembelajaran.

c. Metode yang digunakan pada saat pengawasan kurikulum di MI Nurul Ulum secara umum meliputi kunjungan dan observasi kelas, pembicaraan individu dan musyawaroh.

\section{Evaluasi Implementasi Kurikulum Pesantren di MI Nurul Ulum Kretek Bantul}

Evaluasi merupakan suatu kegiatan yang berusaha untuk mengetahui apakah pelaksanaan kurikulum dapat berjalan sesuai dengan rencana dan memastikan apakah tujuan dan organisasi tercapai. Menurut Dinn Wahyudin tujuan evaluasi adalah menyempurnakan kurikulum dengan cara mengungkapkan proses pelaksanaan kurikulum yang telah berhasil mencapai tujuan yang telah ditetapkan. Evaluasi kurikulum dimaksudkan untuk memeriksa kinerja kurikulum secara keseluruhan yang ditinjau dari berbagai kriteria. ${ }^{16}$ Evaluasi manajemen kurikulum berbasisi pesantren di MI Nurul Ulum adalah sebagai berikut:

a. Evaluasi mengenai kurikulum tidak hanya dilaksanakan setiap akhir saja, tetapi setiap bulan agar masalah yang ada bisa cepat diselesaikan sehingga tidak menumpuk ketika evaluasi diakhir tahun.

b. Metode yang digunakan pada saat evaluasi di MI Nurul Ulum yaitu: rapat koordinasi dan pendekatan personal, madrasah juga melakukan pendekatan secara personal kepada guru, ustad/ustadzah juga siswanya jika ada kendala atau masalah sehingga semuanya dapat diselesaikan secara bersama-sama.

c. Ada beberapa pihak yang terlibat dalam evaluasi kurikulum, diantaranya: ketua yayasan, kepala madrasah, guru, ustadz/ustadzah, dan komite madrasah. Kepala madrasah berperan dalam pengendalian system evaluasi, agar evaluasi dapat dilaksanakan sesuai dengan yang sudah direncanakan. Kepala sekolah bekerjasama dengan guru untuk melakukan evaluasi dengan objektif agar hasil evaluasi sesuai yang diharapkan.

\footnotetext{
${ }^{16}$ Ibid., hlm. 149
} 


\section{D.SIMPULAN}

Berdasarkan analisis hasil penelitian tentang manajemen kurikulum yang dilakukan di MI Nurul Ulum Kretek Bantul maka peneliti dapat menyimpulkan bahwa: Perencanaan manajemen kurikulum berbasis pesantren sudah berjalan sesuai yang telah direncanakan seperti persiapan mengajar dan program sekolah lainnya, perencanan dilakukan pada tahun ajaran baru yang melibatkan kepala sekolah, guru, ketua yayasan dan beberapa komite. Pelaksanaan manajemen kurikulum di MI Nurul Ulum di bedakan menjadi dua tingkatan yaitu tingkat sekolah yang berada di bawah pimpinan kepala sekolah dan kurikulum tingkat kelas yang berada di bawah pimpinan guru. Pengawasan manajemen kurikulum dilaksanakan pada saat berlangsungnya kegiatan pelaksanaan kurikulum dengan menggunakan metode observasi kelas dan musyawarah. Evaluasi manajemen kurikulum dilaksanakan tidak hanya sekali dalam setahun akan tetapi setiap ada kendala sehingga kendala yang ada tidak menumpuk. 


\section{DAFTAR PUSTAKA}

Dawam, Ainurrafiq dan Ta'arifin, Ahmad, Manajemen Madrasah Berbasis Pesantren, Listafariska Putra, 2005

Hairiyah, Konsep Manajemen Mutu Terpadu Dalam Pendidikan" dalam Literasi: Jurnal Ilmu Pendidikan, Vol.VI, No. 1 Juni 2015, 2015

Hidayat, Ara dan Machali, Imam, Pengelolaan Pendidikan, Yogyakarta: Kaukaba, 2012

Mastuhu dalam Maljono Damopoli, Pesantren Modern IMMIM Pencetak Muslim Modern Jakarta: Rajawali Pers, 2011

Kristiawan, Muhammad dkk, Manajemen Pendidikan. Yogyakarta: Deepublish.Mulyasa, 2012. Manajemen Berbasis Sekolah, Bandung: PT.Remaja Rosdakarya, 2017

Sugiyono, Metode Penelitian Pendidikan Pendekatan Kuantitatif, Kualitatif, dan $R \& D$, Bandung: ALFABETA, 2012

Wahyudin, Dinn, 2014, Manajemen Kurikulum, Bandung: PT Remaja Rosdakarya, 2014

Wan Mohd Nor Wan Daud, Filsafat dan Praktik Pendidikan Islam Syed M. Naquid Al-Attas, Bandung: Mizan, 2003 